\title{
Avangard Bir Mabed Olarak Çamlıca Camisi'nin Aktör Ağ Teorisi Bağlamında Çerçevelemesi
}

\author{
DOI: $10.26466 /$ opus.932364
}

\author{
Adem Sağır ${ }^{*}$ - Pınar Memiş Sağır** \\ * Doç. Dr., Karabük Üniversitesi, Karabük/Türkiye \\ E-Posta: ademsagiroglu@gmail.com \\ ORCID: 0000-0003-0763-0518 \\ ** Dr. Öğretim Üyesi, Sakarya Uygulamalı Bilimler Üniversitesi, Sakarya/Türkiye \\ E- Posta: pinarm@subu.edu.tr \\ ORCID: $\underline{0000-0001-9458-8797}$
}

\section{Öz}

Aktör-ă̆ teorisinin çalışmamızda tercih edilir olmasının nedeni araştırma konusu olan Çamlıca Camisi ile ilişkilidir. 2013 yılında resmî tören atma töreniyle yapımına başlanan ve 2019 yılında tamamlanıp açılan Çamlıca Camisi, tasarımın seminer, yarışma, sergi gibi aracılarla tamamlanması, yapım sürecinde malzeme seçimlerindeki taş, kapılar, hallar, imame, minber vb. özelliklerin tümünün "önemle" duyurulması, ayrıca Cami'nin yapım aşamasında katkıda bulunan mimarlar, dernek ve diğer politik aktörlerin yanı sira Cami tamamlandıktan sonra düzenlenen gezi, etkinlik, sergi vb. etkinlikler ile bir araştırma nesnesi olarak Cami'nin nesne olmanın ötesinde çok yönlü ve boyutlu bir ilişki ağı içerisinde olduğunun işaretlerini göstermektedir. Bu çalışma ile amaçlanan Çamlıca Camisi etrafinda örülen toplumsal dilin, örgütler ve failler tarafindan kendilerinin konuştuğu dil ile nasıl inşa edildiğini göstermeye çalısmaktır. Bu amaca yönelik olarak, örgütsel ağın kendisine dikkat çekerek, ağı oluşturan varlkklar arasındaki, biçimsel örgütlenmelerde sabitlensinler ya da edilmesinler, "eylem şebekelerini" ortaya çıkarma çabası güdülmektedir. Çamlica Camisi üzerine yapılan aktör-ă̆ analizinde, Dernek Başkanı, mimarlar, Cumhurbaşkanı, Çevre ve Şehircilik Bakanı ve ziyaretçiler aktörler olarak belirlenirken, büyüklük dine tercüme edilen bir insan olmayan aktör ve konum ise tarihe tercüme edilen insan olmayan aktörler olarak açı̆̆a çıkmıştır. Bu aktantlarm Çamlıca Camisi'nin tarih ve din temelli inşasinda aynı zamanda aktörlerinin dönüştürücü aracılıklarıla zorunlu geçiş noktalarn açarak, diğer aktör/aktantlarm ă̆a ilgilileşme bağları yaratarak, kilitlenme sağladı̆̆ı ortaya çıkmıştır.

Anahtar Kelimeler: $\quad$ Aktör-A $\breve{g}$ Teorisi, Din, Tarih, İstanbul, Çamlıca Camisi. 


\title{
Framing Camlica Mosque as an Avant-Garde Shrine in the Context of Actor-Network Theory
}

\begin{abstract}
The reason why the actor-network theory is preferred in our study is related to the subject of research, which is Çamlica Mosque fits the principle of generalized symmetry. A problematization object, Çamlica Mosque, was started to be built in 2013 with an official ceremony and opened in 2019, completing the design with intermediaries such as seminars, competitions, exhibitions, stone, doors, carpets, imame, pulpit, etc. The study aims to show how a language is constructed by associations and perpetrators using the social language around Çamlica Mosque. For this purpose, an effort is made to reveal the "mobilisation" between the entities that make up the network, whether they are fixed in organizations or not, by drawing attention to the organizational network itself. In the actor-network analysis on the Çamlica Mosque, the president of the association, the architects, the president, the minister of environment and urban planning, and visitors were identified as actors, while grand size was revealed as a non-human actor translated into religion and position as non-human actors translated into history. It has been shown that these actants also produced black boxes in the construction of Çamlica Mosque by creating interessement in translations of non-human actors, based on enrollment with visitors, by opening obligatory passage points with the intermediation of relations between the President of the Association, the architects, the President, the Minister of Environment and Urbanization.
\end{abstract}

Key Words: Actor-Network Theory, Religion, History, Istanbul, Camlica Mosque. 


\section{Giriş}

Bu çalışma bilim adamları kabilesi ve onların bilim üretimine işaret eden laboratuvar yaşamının toplumsal alanın üretimiyle nasıl ilişkilendirilebileceğini bize gösteren (Latour ve Woolgar, 1986) ve adını aktör-ağ teorisi olarak bildiğimiz bir bilimsel yaklaşımın öncülünde şekillenmiş bir çalışmadır. İçinde bulunduğumuz pandemi sürecinde en çok konuşulan konular arasında yer alan laboratuvar çalışmaları, bilim adamının laboratuvardaki egzotik dünyasına yeniden odaklanılmasına ve bilim-toplum ilişkisini yeniden gündeme getirilmesine neden oldu. Tüm dünyada gelişen aşı tartışmaları ile, laboratuvarın kendisinin bir nesne olarak toplumsal alanda farklı örüntüler açığa çıkarması, öznenin ötesine uzanan bir anlam arayışını da kaçınılmaz kıldı. Günümüz toplumlarında gündelik hayatın büyük kısmını kapsayan bilimsel ve teknolojik gelişmelerle açığa çıkan bu tarz kriz anları, bizi, dünya, doğa ve toplumun uyumlu birlikteliğini sorgulamaya zorlamaktadır. Belirsizliklerin riskleriyle boğuşan bir insan tipolojisine ve onun dünyasina atıf yapan bu sorgulama, güvensiz, akışkan ve karmaşa tartışmalarının yükseldiği postmodern düşünce biçimleri içinde karşılık bulmaktadır. Çünkü modern düşünce, doğa ile toplum arasında bir ayrışma yapmıştır. Doğayı kontrol etmenin akılcılığını içeren bu ayrışmada, mekanik evren anlayışı yansıtılır ve "evren parçalara bölünmüş bir bütün" (Arslanoğlu, 1994:39) olarak tanımlanır. "Doğaya egemen olmanın ve onu köleleştirmenin araçlarının" (Capra, 1992; Cevizci, 2016; Akarsu, 1994) sunulduğu bu düşünme biçimi, bugün küreselin içinde olduğu kriz söylemi ve bu söyleme eşlik eden toplumun çöküşü ile giderek sorunsallaştırılmaktadır. Modernizmin geldiği bağlamın geriye doğru bir gidiş olduğunu kriz söylemine eklemleyen ve modernizmin güncellenmesi gerekliliğini gündeme getiren sosyal bilimcilerin ortak referans noktası bilim ve teknoloji ikilisinin toplum ile olan ilişkisinde yeni izahat biçimlerine ihtiyaç duymasıdır (Pappenheim, 2002; Sağır, 2012; Touraine, 2018; Habermas, 2018; Giddens, 2019; Gouldner, 2021). Bugünümüze de meydan okuyan bir fenomen olarak laboratuvar incelemelerinden devşirdiği ontolojik ve epistemolojik çıarımlarla sosyal bilimler için devrimci ve bir o kadar da ufuk açıcı bir sosyal ontoloji ve bir araştırma programı geliştiren (Demir, 2014, s.186) Latour, postmodernistlere no future ve modernlere no past eleştirel atfiyla kullan- 
dığı melez (hybrid) kavramı ile aşmaya çalıştığ1 bu kriz halini doğatoplum arasındaki düalizmin reddiyle başlatır (2008a, s.59).

Latour (2008a)'un "Biz Hiç Modern Olamadık" çalışmasında "ikili karşıtlıkların" reddedilmesi gerektiğini söylemesi bu bağlamla ilişkilidir. Özne ile nesnenin birliği aynı zamanda doğa-toplum birliğine atıftır. Aktör-ağ teorisinin temel kaygısı doğa-toplum ikiliğinde ortaya çıkan karışıklıkları azaltma üzerinedir. Latour'un heterojen ağ dediği bağlam "ince bir mekiğin gökyüzünü sanayiyi, metinleri, ruhları ve ahlak yasasını bağlaması gibi toplumsal olan her şeyi sürekli birbirine ilişkilendirilmesidir" (Latour, 2008a, s.12). Latour'un nesneler dünyasıyla özneler dünyasını birleştirme çabası Gabriel Tarde' nin toplumsal alanı açıkladığı yaklaşımından üretilmiştir. Tarde'nin toplumsal değişmede insan olmayanların yerini tartıştı̆̆ metinlerde iki temel nokta aktör-ağ teorisi için önemlidir. İlki insan etkileşimlerini anlamak için doğa ve toplum ayr1minın önemsiz olduğuna yaptığı vurgu, ikincisi ise makro/mikro ayr1mının toplumun nasıl oluştuğunu anlamaya dair çabaların önünü tıkadığına dair yaklaşımıdır (Latour, 2008b, s. 34; Latour, 2021, s. 31-34). Bu çaba bir teori haline geldiğinde, bilimsel ve teknolojik süreçleri insan ve insan olmayan varlıkların bir araya gelerek oluşturduğu öbekleşmeler yoluyla betimler ve bilimsel bilgi sosyolojisinin insan-merkezli temellerini sarsar (Ansal et al., 2018, s.19).

Latour'un ontolojik bağlamda düşüncelerinin Türkiye'deki karşıllıları bakımından belirtilecek birkaç önemli husus bulunmaktadır. Aktör-Ağ Teorisi'ni (AAT) ana akım sosyolojinin karşısına yerleştiren Latour'un Türkiye'deki sosyolojik karşılıkları iki perspektif aracılığıyla görünür olmaktadır. İlki, görece yeni gelişen, Bilim-Teknoloji-Toplum ${ }^{1}$ (STS) olarak özelleştirilen alandır. Bu bağlamda Ansal ve diğerlerinin (2018) STS disiplinin Türkiye'deki tarihsel yolculuğunu ele alan ve gelecek projeksiyonlarını tartışmaya açan yapısı ile alan kurucu ${ }^{2}$ bir metin olma özelliği taşımaktadır. Diğer perspektif ise, sembolik etkileşimcilik ile daha yakın

\footnotetext{
${ }^{1}$ Örnek kaynak için bknz: ÇALKIVIK, A. (2020). Dünya Siyasetinde Teknolojiyi Yeniden Düşünmek: BilimTeknoloji-Toplum Perspektifinden Alternatif Bir Okuma. Alternative Politics / Alternatif Politika, 12(3), 458-486.

2 Toplum ve Bilim Dergisi'nin 144.ncü olan bu sayısı Bilim-Teknoloji-Toplum alanı çalışmalarını içermektedir. Bu sayıda ayrıca Ebru Yetişkin'in "Bir Başka Laboratuvar: B(ağ)sal Kürasyon" makalesi aktör-ağ teorisi ve diğer teknoloji teorileriyle ilişkileri görmek açısından dikkatle okunmaya değerdir.
} 
bağ kurulan ilişkisel sosyoloji perspektifidir. Temel uygulamalı çalışma metinlerinden kabul edilen Odabaş'ın (2008) Ankara su kesintileri hakkında yaptığ 1 aktör-ağ analizi sonrasında benzeri çalışmalar için referans kaynağ1 olmuştur (Odabaş, 2010; Odabaş, 2016; Kayış, 2017; Gündüz ve Attar, 2020).

Toplumbilimi alanında bu gelişmelerin yanı sıra daha dikkat çekici olan, özellikle AAT sonrası olarak işaret edilen dönem (Michael, 2017; Farías, 2020) itibariyle çalışmaların çoğunluğunun ${ }^{3}$ mimarlık $^{4}$ ve şehir ve bölge planlamaları ${ }^{5}$ alanlarına yığılması; kısmi oranda ise iletişim alanında karşımıza çıkmasıdır. Bu çalışmalar arasında iletişim alanındaki aktör-ağ teorisinin hackvertising stratejisinin kavramsallaştırılması için kullanılabileceğini iddia eden Güler (2019), Burger King'in medya ve popüler kültür aracılığıyla yapmış olduğu reklam çalışmalarını bu bağlamda açmıştır. En yeni çalışmalardan biri de yaptıkları çalışmayı AAT'nin etnometodolojik kökleriyle uyumlu gören Gündüz ve Attar'ın (2020) "Şahsiyet" dizi filminin ağ analizidir.

Yönetim ve örgüt çalışmaları alanında ise aktör-ă̆ kuramı ile ilgili yapılan çalışmalardan birkaç tane kaynağa ulaşılabilmiştir. Bunlardan ilkinde pazarı sosyo-materyal bir gözle değerlendiren Özmen (2019, s.324) aktör-ağ kuramının insanın kendi üretimlerini ontolojik olarak kendi ile ayn düzlemde görmesini să̆layan, adeta bir nesneler dünyası olan pazarlama aleminin araştırılması bağlamında pazarlama düşüncesinin zenginleşmesini sağlayacağını savunmaktadır. AAT gözüyle bir işletmede stratejilerin tasarlanması aşamasına odaklanan Gerekan (2012), temel aktörün, değişimi kendi isteği doğrultusunda gerçekleştirme ve diğer aktörleri de bu doğrultuda yönlendirme amacında iken, muhasebe verileri bir güç aracı olarak önemli bir destekçi rolü üstlenebileceğini ifade etmektedir. Her iki çalışma da teorik tartışmalar olup, bir AAT analizi içermemektedir. Yönetim alanında yer alan, mülteci girişimcilerin Türkiye'de açtıkları restoranlar üzerinden

\footnotetext{
3 Güvenlik alanında karşımıza çıkan ilginç bir çalışma da siber terör ile ilgilidir. E-devlet uygulamalarının herhangi birinin siber teröre açık olduğu iddiasıyla hareket eden Terzi (2019), Aktör-Ağ Teorisi ile gelen insan olmayan aktör kavramları aracılığıyla siber terörün engellenmesi için iyi bir silah olabileceğini ifade etmektedir (s.239).

4 Örnek kaynak için bknz: Mallamahmoud, M. (2015). Bir Mimari Tasarım Sürecinin Aktör Ağ Teorisi ile Okunması (Doctoral dissertation, Fen Bilimleri Enstitüsü).

5 Örnek kaynak için bknz: Kayasü, Serap; Yetişkul, Emine, Bir Araştırma Çerçevesi: Soylulaştırma 2.0. "Planlama", 23, (2014), s.147-152.
} 
Suriye mutfağında yaşanan çeviriyi inceleme amacında olan ve temelde çeviri kuramını baz alan Eryılmaz'ın çalışması (2019) da henüz nihai haline ulaşmamıştır.

Aktör-A $\breve{g}$ Teorisi'nin çalışmamızda tercih edilir olmasının nedeni araştırma konusu olan Çamlıca Camisi ile ilişkilidir. 2013 yılında resmî tören atma töreniyle yapımına başlanan ve 2019 yılında tamamlanıp açılan Çamlıca Camisi, tasarımın seminer, yarışma, sergi gibi aracılarla tamamlanması, yapım sürecinde malzeme seçimlerindeki taş, kapılar, halılar, imame, minber vb. özelliklerin tümünün "önemle" duyurulması, ayrıca Cami' nin yapım aşamasında katkıda bulunan mimarlar, dernek ve diğer politik aktörlerin yanı sıra Cami tamamlandıktan sonra düzenlenen gezi, etkinlik, sergi vb. etkinlikler ile bir araştırma nesnesi olarak $\mathrm{Ca}$ mi'nin nesne olmanın ötesinde çok yönlü ve boyutlu bir ilişki ağı içerisinde olduğunun işaretlerini göstermektedir. Bu çalışma ile amaçlanan Çamlıca Camisi etrafında örülen toplumsal dilin, örgütler ve failler tarafından kendilerinin konuştuğu dil ile nasıl inşa edildiğini göstermeye çalışmaktır. Bu amaca yönelik olarak, örgütsel ağın kendisine dikkat çekerek, ağı oluşturan varlıklar arasındaki, biçimsel örgütlenmelerde sabitlensinler ya da edilmesinler, "eylem şebekelerini" ortaya çıkarma çabası (Czarniawska, 2019, s.9) güdülmektedir. Böylelikle, dini bir figür olarak görülen caminin ne sadece dini tartışmalar ne bellek inşası ne de sadece mimari özellikleri ile değil, araştırmacılara bütün bu özelliklerinin tercüme edilebildiği bir yapı hakkında düşünme, inceleme, konuşma katkılarının sağlanması beklenmektedir.

\section{Bir Araştırma Stratejisi Olarak Aktör-Ağ Teorisi}

Ağ/şebeke (Network), günümüzde birçok alanda kullanılan oldukça popüler bir kavram olarak göze çarpmaktadır. Sosyolojik bağlamıyla birden fazla toplumsal etkileşimle birbirine ilişkilendirilmiş, bu nedenle toplumsal bağ oluşturan bireylere atıf yapmaktadır. Yakın dönemde sıklıkla sosyal medya çalışmaları ve analizlerinde kullanılan bir kavram olarak ağ, karmaşık sistemlerin etkileşimsel bir alanda ilişkileri çerçevelendirmeye gönderme yapmaktadır. Bu çerçeveler, iş birliği, uzlaşma ve karşılıklı güvene dayanmakta ve üst bir eşgüdüm alanı oluşturmaktadır (Aygül, 2006). Topluluğu bir arada tutan temel damarın bireyler arasın- 
daki ilişkilerden kaynaklandığını ve bu ilişkilerin anlaşılmasının toplu-

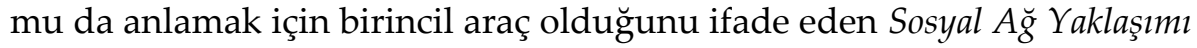
(Gençer, 2017), dışında Castells'in (2013) yeni enformasyon teknolojilerin yaygınlaşmasıyla birlikte ağlar üzerinde oluşan ortak payda ve hedef birlikteliklerini tanımlamak için kullanıldığı $A \breve{g}$ Toplumu kavramı da oldukça önemlidir Bu çalışmaya odak olması bakımından Aktör-Ă̆g Teorisi ise örgütsel çalışmalara sosyolojik ve antropolojik yaklaşımların bir sonucu olarak bilim ve teknoloji konusunda araştırmalarıla bilinen Bruno Latour, Michael Callon ve John Law tarafından geliştirilmiştir.

Aktör-Ağ Teorisi sadece insanları değil, insan olmayanların da sistemin içinde rolü olduğuna ve dolaşımda oldukları alanlarda bulunan varlıklarla girdikleri ilişkilerle şekillendikleri ve özgünlüklerini kazandıkları iddiasını taşımaktadır (Callon ve Latour, 1981; Callon, 1986; Law, 1994; Latour, 1999; Law, 1999). Bu bağlamdan hareketle AAT'nin alan en temel katkısı, sosyal dünyanın insan olmayan aktörler olmaksızın anlaş1lamayacağ 1 şeklindeki vurgusudur (Montegro ve Bilgakov, 2014). Teorinin temel kabulü insanların, edilgen bir nesne olarak kabul edilen insan olmayan aktörlerden üstün tutulmasına karşı çıkış üzerine kuruludur (Latour, 2008). Teori, aktörlerin ne yaptıklarına odaklanmaktan ziyade, kendi eylemleri, öznellikleri, ahlakları ve yönelimleriyle ne sağladıklarının üzerinde durmaktadır (Miles, 2016). AAT'nin ortaya çıkışı ilk olarak Bruno Latour'un 1979 yılında Steve Woolgar ile yazdığı Laboratory Life: The Construction of Scientific Facts başlıklı çalışmada bilgi, ağ içerisinde çeşitli etkileşimlerle makineler, insanlar, binalar, kavramlar, yazılı belgeler vb. aktör/aktantlar aracılığıyla ortaya çıan sosyal bir çıtı olduğuna vurgu yapılmıştır (Latour ve Woolgar, 1986). Latour'un çalışmaları başta olmak üzere alanda öncü birçok çalı̧̧ma da kuramsal olarak AAT'nin geniş bir alanda uygulanmasına neden olmuştur. Kuşkusuz temelde bir çıkış noktası olması bakımından AAT'nin temel motivasyon kaynağı insan-doğa ayrımı yapan modern epistemolojik ayrımı "aktör (actor)" ve "aktant (actant)" kavramlarılla aşma çabasıdır (Latour, 2008; Latour, 2021). AAT, maddi alan ile zihinsel alan arasındaki ayrımı kaldırmak için yeni bir düşünsel çabayı yansıtmaktadır. Akışkan olma halinin ve zamansallığın önemsendiği bu çabanın bir uzantısı olmasıyla ilişkilendirmek gereklidir (Çelikel, 2013). 
AAT, alanyazında "maddeselliğin göstergebilimi" (Law, 1999), "aktörler arasındaki dönüşüm, çeviri ve geçişleri ifade eden bir ağ" (Latour, 1999; Callon ve Latour, 1981; Callon, 1986; Latour, 1992) veya "elementlerin aktörlerin bağlantı veya ilişkiler ağındaki konumları sayesinde kendi mekânsal bütünlüğünü koruduğu alternatif topolojik bir sistem" (Law, 1987; Callon, Law ve Rip, 1986; Law, 1994) benzeri kavramsallaştırmalarla gündeme gelmiştir. Miles (2016) Aktör-A ̆̆ Teorisi'nin içerisinde yer alan "tercüme" sürecinin ayrıca önemsenmesi gerektiğine vurgu yaparken, teorinin tercüme sosyolojisi (translation sociology) olarak da bilindiğine dikkat çeker. Latour (1987) ve Law'ın (1999) metinlerinde tercüme; iki farklı şeyi benzer yapma sürecini, ağları oluşturan aktörlerin yeni aktörleri nasıl süreçle ilgilileştirdiklerini ve ilgilerin yeni yorumlarının önerilmesi ve ilginin yönlendirilmesini şeklinde gerçekleşen durumlarla ilişkilendirilmektedir. Bazı durumlarda ise, mesele bizi çevreleyen kara kutuları açmaktır. Kara kutu metaforu sibernetikten kaynaklanır ve yalnızca girdi ve çıktıyı bildiğimiz, ancak aradaki karmaşık süreçlerle ilgili hiçbir şey bilmediğimiz bir durumu tanımlar (Justesen, 2020, s.331). Ancak AAT araştırmacıları genellikle fenomen nihai anlamda sabit/durağan olmadan önceki süreçlerle ilgilenirler (Justesen, 2020, s.332). Bu süreçler tercüme etrafında analiz edilir ve Latour ve Callon'un (1981) çalışmalarında dört aşamalı bir süreç olarak karşımıza çıkar. Callon (1986) bunları sırasıyla problemleştirme (problematisation), ilgilileştirme (interessement), kayıt altına alma (enrolment) ve harekete geç(ir)me (mobilisation) şeklinde kategorileştirmiştir. Bu bağlamı içerisinde tercüme, bir süreçtir ve asla tamamlanmış bir sonuca sahip değildir; ki tercümenin başarısız olma ihtimali de vardır (Callon, 1984). Tercüme böylece var olmaya ve gelişmeye devam etmek isteyen unsurlar için "zorunlu geçiş noktaları" nın bulunduğu bir coğrafyayı haritalandırır (Callon, 1986, s.27).

Latour, AAT için yol göstericiler sunarken dördüncü olarak "tartışma"lara yer verir. "Tartışmalar analiz için genellikle iyi bir başlangıç noktasıdır çünkü bu tür durumlar tercüme süreçlerinin bir dizi strateji ve taktik aracılığıyla nasıl işlediğini ve sıralı görünen olayların pratikte nasıl kurulduğunu göstermeye yardımcı olur" (Latour, 2005) der. Biz de bu çalışmayla dini anlamda kutsal kabul edilen, mimari anlamda yok sayılmış (Dellaloğlu, 2019) bir alanı örgütleme temelinden tartışmaya aç1- 
yoruz. Burada Aktör-A $\breve{g}$ Teorisi'nin çalışmada nasıl uygulandığına geçmeden önce, ağa ilişkin verilerin nasıl toplandığı bilgisi verilmiştir.

\section{Araştırma Verilerinin Toplanması}

Çamlıca Camisi ağının açılmasında kullanılan araştırma teknikleri arasında, alan notlarının yer aldığı katılımsız gözlem, doküman analizi ve içerik analizi yer almaktadır.

Katılımsız gözlem için, cami açılışı sonrasında sahaya ziyaretler gerçekleştirilerek, mekâna ilişkin gözlemler yapılmış ve gözlem notları tutulmuştur. Katılımsız gözlem süresi kaydı, namaz vakitlerini dikkate alarak, ibadet öncesi ve sonrasını da kapsayacak şekilde dört saat olarak tutulmuştur. Bu süreçte caminin içinde, cami teknolojisini ve büyüklügünü gözlemlemek amacıyla 120 dakika, caminin dışında, konumunu ve yine büyüklügünü gözlemlemek amacıyla 120 dakika geçirilmiştir. Kadın araştırmacı erkek araştırmacıdan farklı olarak, ibadetler için kadınlara ayrılan alanı gözlemleyerek, merdiven sayısı, ses akustiği, minbere yakınlık diğer cami içi görsel imgelerin görünme açlarına ve ibadete katılan kadınların camiyi fiziksel olarak kullanma biçimlerine (asansör, merdiven, abdesthane vb. kullanımlar) ilişkin notlar almıştır. Gözlem süreci ayrıca fotoğraf çekimleriyle de somutlaştırılmıştır. Aralarında internet sayfalarından görsellerin de yer aldığ 1 yaklaşık 100 MsWord sayfasındaki bu notlar, insan olmayan aktör konumundaki özelliklerin analizinde kullanılmıştır.

Araştırmanın yaklaşık 200 MsWord sayfasını bulan doküman analizi, başta dernek olmak üzere ağda yer alan tüm kurumların kendi web sayfalarının analizi ile bu kurumlar hakkında yazılan haber metinleri, ilan, duyuru vb. yazılı tüm medya araçlarını kapsamaktadır. Caminin teknolojisine katılan her bir firmanın bilgilerine ulaşılarak, firmaların halka açık bilgileri yazılı hale getirilmiştir. Bunun yanı sıra sürecin en başında cami için düzenlenen seminerde yer alan tüm bildiriler okunarak, analizi gerçekleştirilmiştir. Başlangıç noktası olarak kabul ettiğimiz 2013 sonrasinda Çamlıca Cami adıyla sosyal medyada yer alan 100 kadar belge ya da fotoğraf elden geçirilmiştir.

Araştırmada içerik analizine dokümanlarda derinleşme sağlanabilmek adına başvurulmuştur. Bu temelde derinlemesine odaklanma gerek- 
li olan aracı konumundaki derneğin hem kendi sayfası hem de hakkında yazılı olan metinler (ortalama 50 MsWord sayfası) içerik analizine tabi tutulmuştur. Benzer şekilde ağın geçiş noktalarını zorlayan mimarlar odası ve derneklerinin basın bildirilerine (25 MsWord sayfası) içerik analizi yapılmıştır.

Araştırmanın en önemli kısıtllı̆ı̆ı araştırma için planlanan derinlemesine mülakatların gerçekleştirilememiş olmasıdır. Bunun iki sebebi bulunmaktadır. Öncelikle camiyi inşa eden mimarlar inşaat süresince medyada yer alan tartışmaları gerekçe göstererek herhangi bir çalışmanın içerisinde yer almak istemedikleri için görüşme taleplerine olumlu geri dönüş yapmamışlardır. Diğer neden ise, başlayan pandemi sürecinde alana yabancı araştırmacılar olarak uzaktan görüşme taleplerimiz kabul görmemiştir. Aktör-ağ analizlerde önemli bir yer tutan mülakatların yokluğu, aktör-ağ analizinin bir yöntem olarak kabulü tartışmaları ile aşılmaya çalışılmıştır.

\section{Aktör-Ağ Teorisi'nin Çamlıca Camisi'ne Uygulanması}

Teorinin uygulanması için yardımcı rehber olarak Michael'ın ağ oluşturmanin "ne", "kim" ve "nasil" olduğu konusundaki ön varsayımlardan kaçınmaya hizmet ettiğini ifade ettiği, analize yönelik terminolojiyi netleştirmek amacıyla sorduğu sorularından hareket etmekteyiz (2017, s.26):

- Actant nedir/kimdir?

- "Oluşum" (association) nasıl kuruldu?

- Kim, "kim tarafından" ya da ne, "neye" tercüme etti?

\section{Actant Kimdir/Nedir?}

Bir nesnenin teknolojik özelliklerinin ona atfedilen değer ve/veya eleştirilerin bu kadar odağında olması, etrafında kurulan ilişkilerin onun bizatihi varlığına bağlı olması, camiyi araştırmanın başat nesnesi olarak kabul etmeyi gerektirmektedir. Aktör-A $\breve{g}$ Teorisi'nin temel kavramı olan Aktant (eylemci), bir eyleme muvaffak olan veya maruz kalan bir varlık veya şeydir (Czarniawska, 2017, s.2). Bu fikir sadece insanlara değil, do- 
layisiyla hayvanlara, nesnelere ve kavramlara da uygulanabilir (Greimas ve Courtés, 1982: 5'den akt. Czarniawska, 2017, s.2).

Cami, geçmişten bugüne taşıdığ yatının merkezinde yer alması, gündelik alanın kurulduğu ilişkisellik inşası, dinin sembolleşmesinin yanında politik güç ve devletin söylemsel bir alan olarak da inşa ettiği içeriği başta olmak üzere birçok açıdan mimarisinin ötesine geçen bir içeriğe sahip olmuştur. Yakın yüzyılda din temsiliyeti anlamının paranteze alınmasıyla hem Avrupa'da hem Türkiye'de politik, ekonomik ve mimari birçok tartışmayı içeren bir materyal alana dönüşmüştür. Bu materyal alan, yapısal olarak durağan olmakla birlikte aktörleri aracılığıyla etrafı sarmalanan bir ağa dönüşmektedir. Avrupa'daki camiler İslamofobi tartışmalarının merkezinde yer alırken Türkiye'de de çok yönlü tartışmaların ana teması olmuşlardır. Çamlıca Camisi'ne gelen yol, Türkiye' de oldukça uzun bir izleğe sahiptir. Cumhuriyet döneminden itibaren yapımından kullanımına, tarihsel kimliğinden mimari kimliğine kadar birçok kritik dönüm noktasının köşe taşını oluşturmuştur.

29 Mayıs 2012 tarihinde dönemin Başbakanı tarafından "Çamlıca'da dev cami, İstanbul'un her yerinden görülecek şekilde tasarlandt. Üsküdar'ın camlarında artık farklı yansimalar olacak" söylemiyle fikirsel olarak ortaya çıkışını temsil eder. Cami'nin konumlandırıldığı alan olarak Çamlıca Tepesi'nin "Büyük Çamlıca Özel Proje Alanı" olarak ilan edilmesiyle devam eden sürece farklı aktörlerin dahil olmasıyla geniş bir aktör/aktant katılımıyla "dev(asa)" bir ağa dönüştüğü görülmektedir. Bu ağ, aynı zamanda tasarımından ve inşasına teknolojik araçlarla çerçevelenmiştir. Teknolojinin cami için başat bir unsur olması, AAT'nin ruhuna uygun biçimde Çamlıca Camisi'nin bir "laboratuvar" olduğu ve "aktörler tarafından nasıl üretildiğinin antropolojisinin yapılabileceği" (Latour, 1979) bağlamı içermektedir.

Çamlıca camisi Türkiye'de yapılan sayısı pek çok olan camilerden herhangi biri değildir. Tasarı aşamasından, yapım aşamasına, açılışından, kendisinden sonra inşa edilmeye başlanan/edilecek olan camilere kadar birçok alanda tartışmalar uyandırmış ve kendisi açıkça bir "temsil" niteliği kazanmış bir camidir. Bu imgenin göstergebilimsel değerini ortaya koyması açısından önemlidir. Law'ın (1999:4) Aktör-A $\breve{g}$ Teorisi için kullandığı "maddeselliğin göstergebilimi" tanımlaması tam da bu- 
rada camiyle örtüştügü yerlerden birisidir. Teoriye göre maddesellik bir nesnenin gövde veya töze sahip olmasını ifade etmektedir. Bu bağlamda aktör/aktantlar sadece diğer varlıklarla olan ilişkiler birleşmesi ya da ilişkisel maddesellik aracılığıyla maddeselliğe veya töze sahip olur (akt. Miles, 2016). Diken'in (1997:87) serbest birleşme olarak çevirdiği ve hem insan hem de insan olmayan unsurları yani aracıları harekete geçiren mobilize eden girişimciler olarak aktardığ 1 bu durum, Çamlıca Camisi'nin de her yönüyle "dev(asa)" bir ağ olduğunun besleyici kabulü olarak düşünülmüştür. Diğer önemli olan nokta da Türkiye'nin geçirdiği iddia edilen muhafazakâr dönüşümünde Çamlıca camisine yapılan atıflardır (Parlak ve Aycan, 2016; Bora, 2017; Oral, 2017; Batuman, 2018; Akyıldız, 2019; Korkmaz, 2019; Hammond, 2019; Parlak, 2020; Çınar, 2020; Oral, 2020; Adaman ve Akbulut, 2020).

Bu iki bağlamı birbirine bağlı kılan nokta, gelecek öngörüleriyle ilişkilidir. Coğrafi konumu itibariyle Çamlıca'nın tercih edilmesinin sonrasında onu takip eden konumlandırmalar önemli kabul edilmiştir. Özellikle hemen peşi sıra Levent'te Barbaros Hayrettin Paşa adıyla inşa edilmeye başlanan caminin Çamlıca'ya göre konumlandırılması, Taksim Meydanı'na yapılan cami ${ }^{6}$ ve Ayasofya Cami'nin ibadete açılması bu konumlandırmanın topoğrafyasına gönderme yapar. Çamlıca Camisi'nin avangartlığ1 da kuşkusuz gelecek öngörülerinin ortaya çıkışının öngörüldüğü bu topoğrafyayla ilişkilidir. Girişimler, inşa edilmekte olan ama bu inşanın birbirine bağlı dinamik bir süreç izlediği görüntüsünü vermektedir. Bu dinamikliğin ağa benzediğini iddia etmek yanlış olmayacaktır. Çamlıca ile erken dönem ağın oluşumunu gördügümüz ve onu takip edecek bir dizi ağların imgeler üzerinden genişlemesinin incelemeye konu edilmesi tam da AAT'nin kendine biçtiği roldür (Latour, 1999). Ağa çıkar bağlarıyla dahil olanlar, ağın devamlılığını sağladığı gibi çok beklendik bir şekilde bu dinamikliği durağanlığa dönüştüren kara kutular açığa çıkaracaklardır. İşte bu çalışmayla tam da gerçekliğin yapısal inşasında

\footnotetext{
61968 yılında gündeme gelen Taksim Camisi, 28 Mayıs 2021 Cuma günü ibadete açılmıştır. Caminin Istanbul'un Fetih tarihinden bir gün öncesinde açılması diğer camilerde olduğu gibi belleği tamamlayıcı dönüşümsel izler taşımaktadır. Benzeri bir başka adım ise 4 Haziran 2021 günü Zonguldak Uzun Mehmet Camii'nin törenle ibadete açılması ile atılmıştır. Türkiye'nin farklı yerlerinde benzer örnekleri sıralamak, Çamlıca Camisi'nin ardı sıra gelen ağ etkisini göstermesi bakımından önemlidir. Örneğin Trabzon'da yapımına başlanan Şehir Camisi Külliyesi'nin de aynı ağın devamı olduğu görülmektedir.
} 
herkesçe bilinen ve normalleştirilen kara kutulara dönüşmeden, ağı açmak amaçlanmaktadır. Bir AAT uygulayıcısı olarak ağların tezahür ettiği yollara deneysel şekilde nasıl erişebileceğimizin sorusunun (Michael, 2017, s.49) yanıtını bu şekilde vermekteyiz.

\section{“Oluşum": Kim, “Kim Tarafından” ya da Ne, “Neye” Tercüme Etti?}

Çalışmanın bu kısmında Latour (1999)'un Pandora's Hope çalışmasında "pandoranın kutusu açılmall, aktantların demokratik evrenine geçilmeli" şeklinde yaptığ 1 yol gösterici mottoya atıfla analiz temaları (Tablo 1) verilmiştir. Analiz temaları aynı zamanda "zihin ile bedenin bölünmesine karşı ağların haritalanması" (Hughes, 1983) çabasının temsilidir.

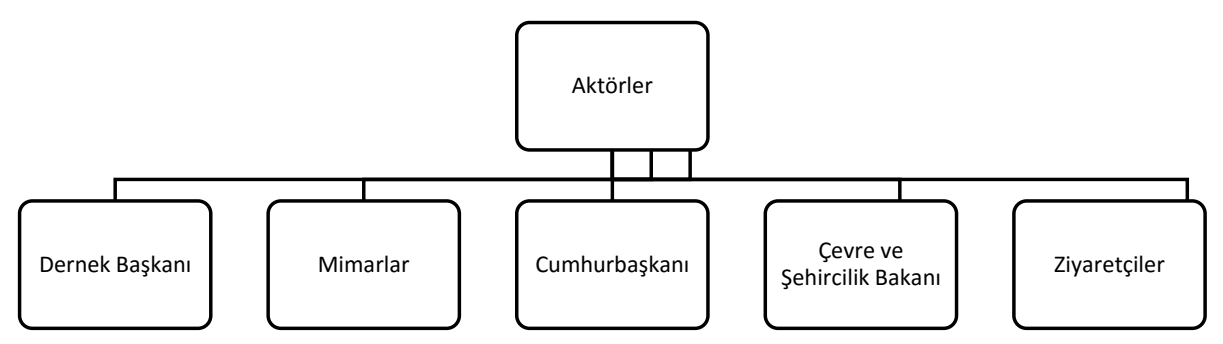

Şekil 1. Çamlıca Camisi aktör-ăg analizi: Aktörler 

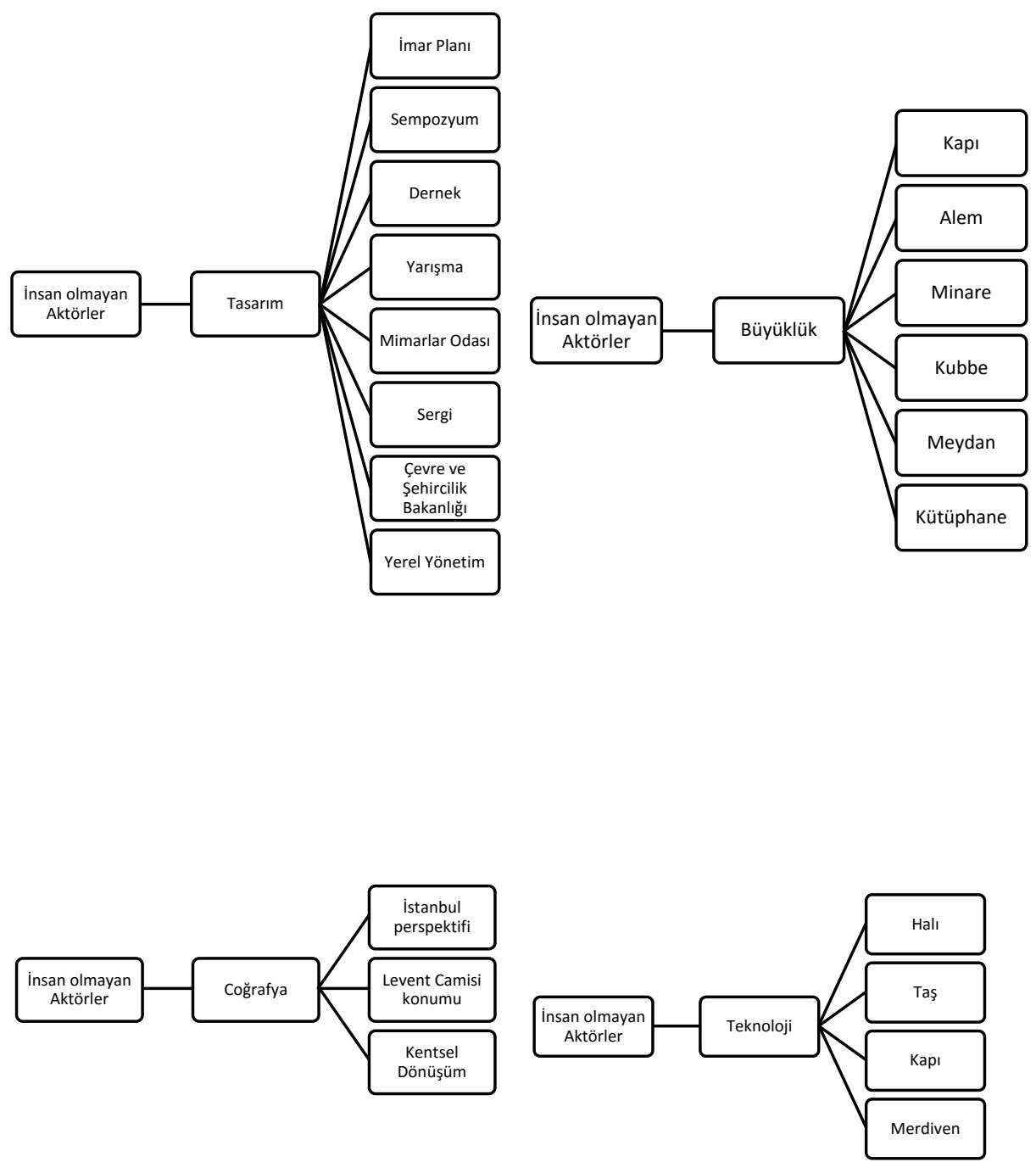

Şekil 2. Çamlıca Camisi aktör-ă̆ analizi: İnsan olmayan Aktörler (Aktantlar)

Aktör/aktantların demokratik birlikteliği, genelleştirilmiş simetri olarak (Latour, 2005) tanımlanır. Böylece Çamlıca Camisi, insani eylemlerle 
nesneler dünyasının eşit derece birlikteliğinden oluşan bir ağ olarak örgütlenmiştir. Ağın içerisinde "tüm varlıklar/oluşumlar eşit derecede eylemde bulunma becerisine sahipliği”" (Kasapoğlu ve Odabaş, 2009) önemli bir göstergedir. Latour'un (2005) eylemde bulunan insan veya insan olmayan nesneleri kapsayan aktör ya da aktantlar; Çamlıca Camisi (ÇC) ağında, dernek, tasarım, coğrafya (fiziksel konum), büyüklük ve teknoloji olarak belirlenmiştir.

Latour'un (2005) eylemin yasallaşmasında katkı sağlayan araçlar (mediator) olarak ifadelendirdiği ağ 1 dönüş̧ürrücü aracı aktör/aktant, İstanbul Cami ve Ĕ̆itim-Kültür Birimleri Yaptırma ve Yaşatma Derneği kabul edilmiştir. Dernek, ağ etrafında bütün aktörleri tercüme süreciyle ilişkilendiren aracıdır. İnternet sayfasında kuruluş yılının 2011 olarak verildiği görülür. Derneğin sayfasında ÇC'den ilk bahsedilen tarih 29 Mayıs 2012'dir. Derneğin sayfasında aracillk rolüne atıf yapması açısından tüm çalışanlarm el birliğiyle, sebepler aleminde, geleceği şimdiden düşünen bu proje ile bir eser inşa etmeye başlaması söylemi önemli bulunmuştur. Derneğin aracılığını güçlendiren ilişki ağları ise hem el birliği içinde çalışacak isimsiz kahramanlar'a atıfla gönüllüler hem de ekonomik, politik ve toplumsal aktörleri ağla ilgilileştirmesidir. Derneğin rolü, Cami etrafında bütün aktörlerin toplanmasına aracılık etmektedir. Bu açıdan kuruluşunu takiben bütün faaliyetleri Cami'nin yapılması ve tamamlanması üzerine kuruludur. Cami için proje yarışmasının açılması, takibi ve sonuçlandırılması ise başlayan rolün, ekonomik aktörlerin bir araya getirilmesi, yönetsel süreçlerin takip edilmesi, medyaya ilgili süreçler hakkında bilgilendirme yapılması, kamuoyunu ikna gibi birçok rol de dernek merkezi bir konumda yer almaktadır.

Latour' un (2005) "eylemde herhangi bir etkisi olmayan insan ve insan olmayan şey" olarak açıkladığı transfer aracı (intermediary) her aktörün bileşenidir. Tasarımın transfer araçları olarak yarışma, yerel yönetim, sempozyum, bakanlık, imar planı, sergi ve mimarlar odasıdır (Bkz. Şekil 1).

Tasarım, tasarlamak eylemine karşılık Çamlıca Camisi için bir plan yaratma ve geliştirme sürecini, "tasarı" kavramına karşılık olaraksa bir plan ya da taslağın sonucunu ifade etmek için kullanılmıştır. Diyanet İşleri Başkanlığı́nın Mimar Sinan Güzel Sanatlar Üniversitesi ile düzenlediği “Gelenekten Geleceğe Cami Mimarisinde Çağdaş Tasarım ve Teknoloji- 
ler" konulu sempozyum, 2012 yılında Çamlıca Camisi'nin etrafında yaşanan tartışmalar sonrası aktörlerin buluştuğu bir alandır. Oral (2017) sempozyumun çağdaş tasarım ve modern temalar gündemini konuşma kayg-sını taşıdığını ancak muhafazakâr kavramıyla ifade edilebilecek bir düstura sahip olduğuna dikkat çekerken, aslında Çamlıca Camisi' nin tercüme sürecinde sıklıkla kullanılan tarih ve din kavramlarının merkeziliğini öngörmüştür.

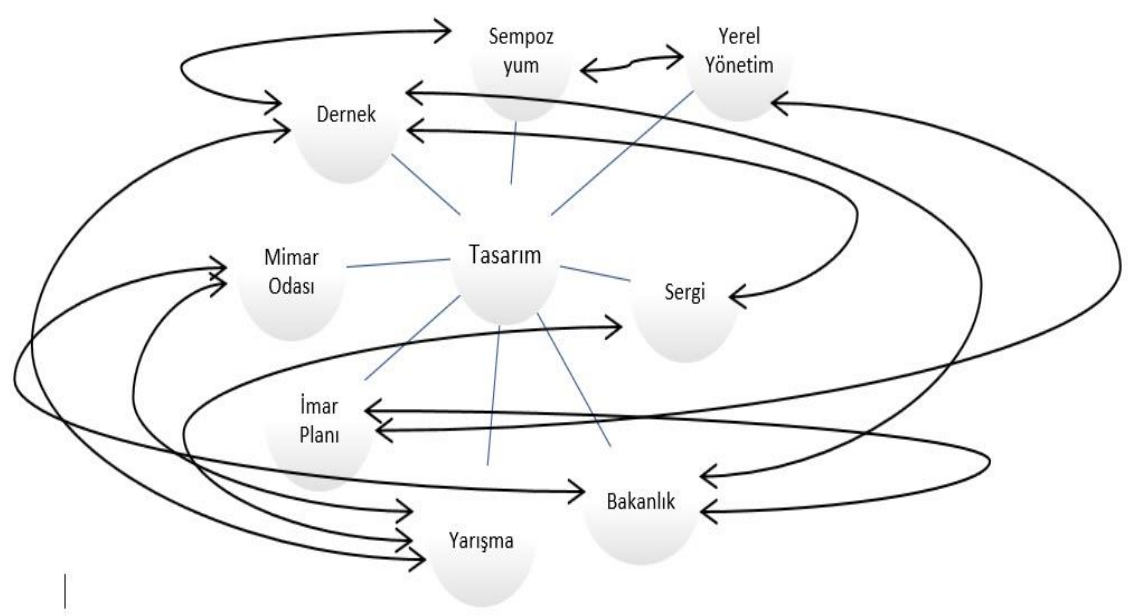

Şekil 3. İnsan Olmayan Aktörler-1: Tasarım

Cami'nin yapılacağı alanla ilişkili öncesinde ve sonrasında yerel yönetim ve bakanlık tarafından yapılan imar planı değişiklikleri hem fiziksel alanın hazırlanmasında hem de Cami'nin çevresinin konumlandırılmasında etkili bir aracı olmuştur. Analizin bu bağlamı aynı zamanda Cami ile ilişkili ilk zorunlu geçiş noktasının ortaya çıtığ kim caminin inşa edilmek istenen alan imara açık olmadığ gerekçesiyle kayıt altına alma süreci sekteye uğramıştır. Bu karşı koyma, diğer aktant/aktörleri ilgilileştirmeye yönelik ilk zorunlu geçişi oluşturmuştur. Birinci zorunlu geçiş noktası olarak Çevre ve Şehircilik bakanı olan aktör aracılığıyla yapılan imar planı değişikliği ile tercüme edilen şey tarih'tir. Cami'nin kamuoyuna açıklandığı zaman olarak beliren 29 Mayıs İstanbul'un fethinin gerçekleştiği gün olması, Üsküdar bölgesinin Anadolu- 
luğu ve Anadolu-Türk İslam geleneğini temsil ettiğinin varsayılması (Demiroğlu, 2017) bu bağlamda içeriği doldurmaktadır. 4 Haziran 2012'de yapılan imar değişikliği sonrası “Büyük Çamlıca Özel Proje Alanı"na bir aktör olarak ilgilileştirilen Mimar'dan sonra hem Mimarlar Odası'nın hem de yarışma ve yarışmada dereceye giren tasarımların sunulduğu serginin ağa dahil olduğu görülür.

Çamlıca Camisi'nin coğrafi konum (fiziksel alan) içerisinde transfer aracılar olarak İstanbul silueti, kentsel dönüşüm, Levent'te göre konum ve diğer cami mimarileri sıralanmıştır. Bakanlık tarafından öngörülen planda "Çamlıca Özel Proje Alanı" olarak belirlenen alanın oldukça geniş bir alanda konumlandırıldığı, yapılacak dini tesisin yanında birçok sosyal alanın da yapılacağı öngörüsünde bulunulmuştur. Cami'nin nicelik olarak kapladığı alanın büyüklügü̈nün yanında "proje alanı"nın da dışarıya doğru büyük bir alanı içerisine aldığı görülmektedir. Kentsel dönüşümlerle Cami'ye göre yeni bir alan inşası yapıldığı/inşa edildiği görülürken, sonraki süreçlerde tercüme edilen şeyin, İstanbul'un tamamına uyarlanması söz konusudur. Özellikle Çamlıca merkeze alınarak diğer cami mimarileri ve konumlarının seçilişi dikkat çeken ilişkiler olarak kabul edilmiştir.

Caminin konumu üzerinden yapılan, bir ibadet mekânı olarak cami ile İstanbul'un nadir yeşil kalan alanının seçilmesi ikileminde büyüyen tartışmalar, ağ için bir sonraki geçiş noktasını oluşturmuştur. Burada dönemin Cumhurbaşkanı Erdoğan'ın 29 Mayıs 2012 tarihinde Üsküdar'da yaptığ kabul edilmiştir. Erdoğan'ın "Çamlıca'da bu dev cami, İstanbul'un her yerinden görülecek şekilde dizayn edildi. Üsküdar'ın camlarında artık farklı yansımalar olacak" söyleminden hareketle tercüme edilen şey ise "büyüklük" olarak tespit edilmiştir. Büyüklük tartışmaları, bu çalışmanın niçin teknik üzerinden gittiğini ve AAT perspektifinde yapıldığının da önemli bir zeminidir. 


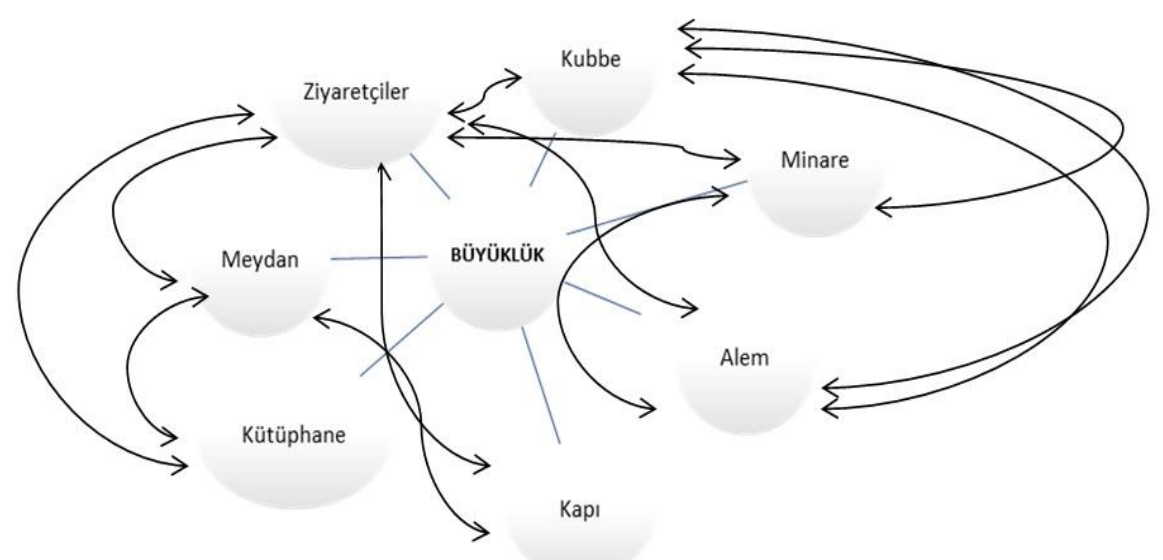

Şekil 4. Insan Olmayan Aktörler-2: Büyüklük

Çamlıca Camisi İstanbul'un en yeni simgesi olarak adlandırılırken ona atfedilen büyüklük uzantıları ise heybetli, görkemli, yeni, büyük, eşsiz, Cumhuriyet tarihinin en büyüğ̈̈, ihtişaml, muazzam ve dünyanın en büyüğ̈̈̈ şeklinde karşımıza çıkmıştır. Çamlıca Camisi örneğinde büyüklük, aynı zamanda etrafını da dönüştüren ve yutan bir kapsama sahiptir. Nitekim bir transfer aracı olarak kabul edilmiş kentsel dönüşümlerin Cami'nin çevresini değiştirmesi bu bağlamda dikkat çekicidir (Çavdar, 2020; Toki Haber Dergisi, 2020). İstanbul'un her yerinden görülecek olmasıyla eşgüdümlü ilerleyen büyüklük, Latour'un (1997 s.122) aktörlerin zincirleme oluşturdukları ağın içinde gücün ne şekilde ortaya çıktığıyla yakından ilişkilidir. Latour, gücün zincirin gerçekliği tanımlama ve yaratma kabiliyetinde olduğu noktalarda açığa çıktığına değinmektedir. Bu bağlamda göre aktör-ağ ne kadar uzun ne kadar etkin, ne kadar kararlı, ne kadar gerçek ise, o kadar güçlü olmaktadır (Latour, 1997). Çınar'ın (2020) çalışmasında büyüklük ile meydan arasındaki ilişkiselliğin nasıl oluştuğu sorunsalı da kendiliğinden açığa çıkar. Çınar'a göre büyük ebatlarıyla camiler, çevresindeki herşeyin kendilerinden küçük hale getirildiği yeni bir meydan anlayışı yaratmaktadır. Böylece alanın domine eden ve dö- 
nüştüren ölçekleriyle ortaya çıkan amacın, içine girildiğinde sadece bir ibadet mekânı olmasının dışında, dışarıda dursanız da iktidarın gösterişinin görmezden gelinemeyecek büyüklügüünün kanıtlanması olduğu vurgusu yapılmaktadır. Ergi (2020) ise çalışmasında kentsel dönüşümlerle "yerinden edilen mekân ve insanlara" atıf yaparken, "temsil ettiği dünyevi/ruhani büyüklüğe karşı boyun eğme talebinin" Cami'nin içinde ve dişında doğrudan büyüklüğüyle ilişkili olduğuna dikkat çekmiştir.

Ağın, fiziksel tamamlanmasından sonra ağın durağanlaşması için ağa katılan aktant ise caminin tanıtım faaliyetleri olarak tespit edilmiştir. Özellikle, caminin büyüklüğü karşısında dol(durula)mayacak bir cami karşıt söylemine karşı geliştirilen, ibadet dışı özel amaçlı ziyaretler önemli bir yer değiştirme (displacement) aktörüdür. Bu süreçte çoğunluğunu yerel yönetimler tarafından düzenlenen turlar bu ağın yeni aktörleri arasında karşımıza çıkmaktadır. Büyüklüğün diğer aktörler tarafından "göz"lemlenmesi için diğer bir aktör olarak ziyaretçiler devreye girmiştir. Ziyaretçiler de bir yer değiştirme aktörü olarak bu ağ durağan biçime getirilmiştir. Camiye gelen her bir ziyaretçi ile caminin büyüklüğü ağ1 genişleyerek o durağanlığı sürdürebilir hale getirmektedir (Chen ve $\mathrm{Wu}$, 2021).

Aktör-ağ teorisinin köklerinde bilim ve teknolojiyi anlama çabası yattığı düşünüldüğünde aslında buraya kadar analizin çerçevesini çizen temel noktaların teknolojinin bir aktör olarak düşünülmesini zorunlu kılmaktadır. Kubbe, minare ve kapının da dahil olduğu büyüklüğü oluşturan aktör ve aracıların teknolojinin kullanılma biçimiyle doğrudan ilişkili olduğunu söylemek mümkündür. Bu nokta aynı zamanda AAT'nin teknobilime yüklediği "daha geniş ve daha güçlü ağların yaratılması" (Sismondo, 2016) sürecine atıf yapar. Bağlamı merkeze koyarak analizin öznesi olarak Çamlıca Camisi, Türkiye'nin yerli ve milli teknoloji savının bir uzantısı olarak yapıda kullanılan bütün aktör/aktantların teknolojiyle ilişkili atıfları oldukça önemlidir. Teknolojiye yapılan vurgunun Cami'nin yaptırılma sürecinde aracı olan dernek başkanının verdiği birçok röportajda yer alan teknolojik vurgular destekleyici durmaktadır. Engelliler için hazırlanan iç ve dış mekân anlatıları ile başlayan teknoloji vurgusu, kubbede nano-teknolojinin kullanılmasına kadar uzanan bir yap1 unsurlarını tanımlamaktadır. Kubbede kullanılan alemin nanoteknolojiyle hazırlanmış oluşu, aynı aleme yüklenen dünyanın en büyüğ̈̈̈ 
atfının bu açıdan teknoloji ile büyüklük gerçekliğini sentezleyen önemli bir göstergedir. Mimarlar Odası'nın Cami'nin mimari konumunu tartışırken kullandığ günümüzün beton ve çelik teknolojiyle daha büyük kubbe yapılmasını öven söylemlere dönük eleştiri de benzer şekilde teknolojinin altını çizmektedir. İşitme problemi yaşayanlara dönük hazırlanan frekans sistemi, görme problemi yaşayanlara dönük din görevlisiyle kılınan namazlarda ritüellere bağlı geliştirilen uyarıcı 1şık sistemi, kubbede Mimar Sinan'ın Süleymaniye Camisi'nde kullandığı sistemin benzeri delikler açılıp kubbenin içerisine kimyasallar verilerek aynı etkinin yaratılması, ezanın Topkapı Sarayı'ndan duyulmasına dönük yapılan özel ses sistemleri, iç ve dış aydınlatma biçimleri, özel olarak kullanılan halılar ve bunları üreten teknoloji, demir-çelik ürünleri ve taş unsurları başta olmak üzere birçok aracı Cami'nin çıkar temelli ilgilileşen aracılarıdır.

\section{Sonuç}

Umberto Eco, mimarlık bir iletişim olgusudur derken aslında onun bir ağ olduğunu ve ilişkiler sisteminden örülü olduğuna gönderme yapmıştır. Dolayısıyla mimari bir eserin analiz nesnesi olması, aynı zamanda onunla ilişkili birçok konunun tartışılmasını ve ağa eklemlenmesini zorunlu kılar. Tarihsel koşullar, toplumsal alan, gündelik hayat, din, kültür, ekonomi, teknoloji ve zihniyet bu ağın parçalarını anımsatır. Mimari yapının bir süreç olması, onun inşasında bir araya gelen her türlü özne-nesne ilişkisinin de dikkate alınmasını gerektirir.

AAT analizinin faili olarak tanımladığımız Çamlıca Camisi'nin bir ağ olarak kabul edildiği ve onun etrafında oluşan etkileşim şebekelerinin tartışmaya açıldığı bu çalışma, Anadolu'yu Avrupa'ya manevi bă̆layan, Türk-İslam tarihinin önemli yapıları arasında yerini alacak, nesillere miras, bir başka miras olarak kendini problemleştirmesi ile başlatılmıştır. Büyüklük dine tercüme edilen, konum ise tarihe tercüme edilen birer insan olmayan aktörlerdir. Bu aktantların Çamlıca Camisi'nin tarih ve din temelli inşasında aynı zamanda Çevre ve Şehircilik Bakanı ve Cumhurbaşkanı aktörlerinin dönüştürücü aracılıklarıyla zorunlu geçiş noktaları açarak, diğer aktör/aktantların ağa ilgilileşme bağları yaratarak, kilitlenme sağladığı ortaya çımıştır. Sözcülerin/Aktörlerin Çamlıca Camisi'ni sıfır noktası atfıyla inşa ettikleri bu mimari eserin konumlandırıldığı alanda nasıl 
bir karakutuya dönüş(türül)ebileceğinin detaylı betimlenmesine ulaşılmiştır.

Aktörlerin/aktantların birbirleriyle çıkar temelli ilişkilenerek harekete geçtiği bir bağlantılar oluşumu gerçekleştirdiği, böylece ağı sabit kılacak aracılar, failler (hatta belki melezler) ekleyebileceği bu AAT analizi, Cami'nin topoğrafyasının nasıl işleyeceği konusunda önemli bir başlangıç sunmaktır. Michael (2017, s.43), bir ağı dayanıklı hale getirenin ne olduğu sorusuna cevap olarak, dayanıklılık, bir ağın devamını ifade eder: Böyle bir $a \breve{g}$, rolleri 'durağan' olan aktörlerden, sıkıca kapalı kalan kara kutulardan, gerçekten değişmez olan değişmez harekete geçiricilerden, ihanete direnen oluşumlardan oluşur demektedir. Buna göre, Çamlıca Camisi büyüklük ve konum aracılığıyla topografya için bir kara kutu oluşturmaktadır. Callon'a göre (1991) kara kutu olarak bir ağ, diğer kara kutularla ilişkilendirilebilir; yani, başka bir ağda bir öğe haline gelebilir. Bu çalışmayla AAT'nin arzu ettiği şekilde kara kutunun açılması ise başka kara kutuların varlığını görünür hale getirmiştir. Gelecek çalışmalar için mesele bu diğer kutuların açılması ve özne-nesne düzleşmesinde yeni detaylı hikayelendirmeleri yapılacak örgütlenmeleri yaratıcı şekilde fark edebilmektir.

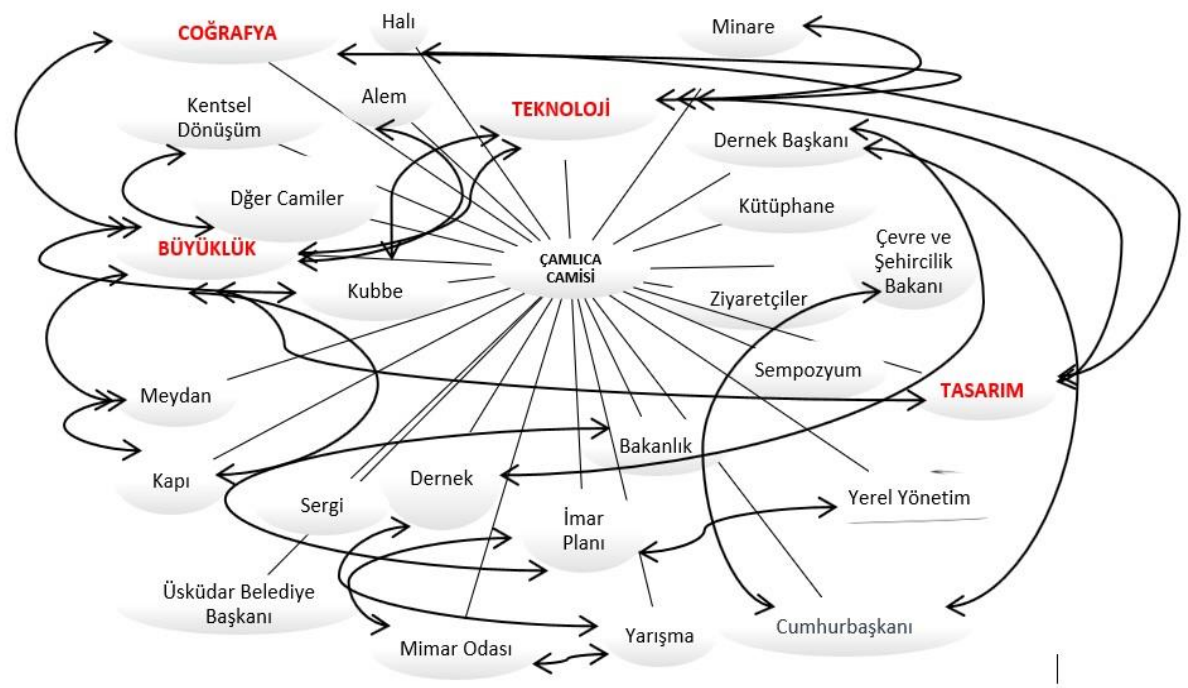

Şekil 5. Çamlıca Camisi'nde Tüm Aktörlerin İç İçeliği 
EXTENDED ABSTRACT

\title{
Framing Camlica Mosque as an Avant-Garde Shrine in the Context of Actor-Network Theory
}

\author{
Adem Sağır - Pınar Memiş Sağır \\ Karabük Univesity-Sakarya University
}

The reason why the actor-network theory is preferred in our study is related to the subject of research, which is Çamlica Mosque fits the principle of generalized symmetry. The study was initiated by problematizing the statement that "a legacy to generations, a distinct legacy that connects Anatolia to Europe spiritually and will take its place among the important structures of Turkish-Islamic history".

A problematization object, Çamlica Mosque, was started to be built in 2013 with an official ceremony and opened in 2019, completing the design with intermediaries such as seminars, competitions, exhibitions, stone, doors, carpets, imame, pulpit, etc. All of its features that the architects, associations, and other political actors who contributed to the construction phase of the Mosque, as well as trips, events, exhibitions, etc., organized after the Mosque completed, has been advertised with "great importance." As a research object with these activities shows that the Mosque is in a multifaceted and dimensional network of relationships beyond being an object. The study aims to show how a language is constructed by actors using the social language around Çamlica Mosque. Unlike previous studies, we chose to examine the construction of language through the organization of the mosque as a material object. For this purpose, an effort is made to present the "mobilisation" between the actors that make up the network, whether they are emerged in organizations or not, by drawing attention to the organizational network itself. Here, ANT has became our guide in achiving our aim. We accepted the Çamlica Mosque as the agency in the relation of actors to each other in the network of ANT analysis. Subsequently, actors are the material objects that exert agency, were opened for discussion as a network.

The research techniques used to analyze the Çamlica Mosque network are an unattended observation with field notes, document analysis, 
and content analysis. For the unattended observation, field visits were made after the Mosque finished. The unattended observation time record was kept for four hours, including before and after prayer, considering the prayer times. During the field visit, observation notes were taken. Later, these notes were enriched with visuals and used in the analysis of non-human actor characteristics. The document analysis of the research comprises the web pages of all institutions in the network, especially the association, and the news texts, advertisements, announcements, etc. It covers all written media. By reaching each company participating in the technology of the mosque, the public information of the companies was reviewed. Besides, all the papers in the seminar which is organized for the mosque at the beginning of the building process were read and analyzed. Content analysis was used in the research to deepen the document analysis. For the content analysis, the web page of the association and the texts (academic or non-academic) written about it were subjected to content analysis. Similarly, content analysis was made for the press releases of architect chambers and associations that force the passage points of the network.

In the actor-network analysis on the Çamlica Mosque, the president of the association, the architects, the President, The Minister of Environment and Urban Planning, and visitors were identified as actors, while the project, technology, the location and grand size was determined as non-human actors. According to the findings of the research, it was understood that grand size as a non-human actor translated into religion and the location as a non-human actor translated into history. It has also appeared that these actants produced black boxes in the construction of the Çamlica Mosque by creating interessement in translations of nonhuman actors.

This ANT analysis, in which actors/actants can create a connection in which they act by interrelating with each other based on interest, thus adding agents (maybe even hybrids) that will make the network stable, provides an important start on how the topography of the mosque will function in future. Michael (2017, p.43), in response to the question of what makes a network resilient, said, "Resilience refers to the continuation of a network: Such a network refers to the continuation of a network: from actors whose roles are "stationary", from tightly closed black 
boxes, to what is truly immutable is invariant". It consists of mobilizers, formations that resist betrayal," he says. Accordingly, Çamlıca Mosque forms a black box for topography through size and location. According to Callon (1991), a network as a black box can be associated with other black boxes; hat is, it can become an element in another network. With this study, opening the black box as desired by ANT made the existence of other black boxes visible. For future work, the challenge is to open these other boxes and creatively recognize the organizations in which new detailed narratives will be made in subject-object straightening.

\section{Kaynakça/References}

Adaman, F. ve Akbulut, B. (2020). Erdoğan's three-pillared neoliberalism: Authoritarianism, populism and developmentalism. https://doi.org/10.1016/j.geoforum.2019.12.013.

Akrich, M., Callon, M. ve Latour, B. (2002). The key to success in innovation part 1: The art of interessement. International Journal of Innovation Management, 6(2), 187-206.

Akyıldız, S. (2019). Yeşil alan mı ibadethane alanı mı? Dil, din, pratik ekseninde validebağ direnişi. Sosyoloji Araştırmaları Dergisi, 22(1), 1-31.

Ansal, H., Ekinci M., Kaşdoğan, D. (2018). Bilim, teknoloji ve toplum çalışmaları'na bir giriş. Toplum ve Bilim, 144, 9-37.

Atlı, M. (2017). Türkiye'de cami mimarlığı tartışması nerelerde tıkanıyor? Kubbeyi yere ve/veya Çamlıca Tepesi'ne koymak. T. Bora (Der.) içinde, İnşaat Ya Resullullah (s.55-76). İstanbul: İletişim Yayınları.

Aygül, C. (2006). Şebeke kuramlarına eleştirel bir bakış. Memleket SiyasetYönetim, $1,141-153$.

Batuman, B. (2018). New Islamist architecture and urbanism: Negotiating nation and Islam through built environment in Turkey. London: Taylor \& Francis.

Bergi, B. (2020). Yeni Türkiye sembolizmi: Büyük Çamlıca Camisi. https://www.muratbergi.com/index.php/2020/09/05/cemaatsiz-cami-buyukcamlical, Et. 15.11.2020.

Bora, T. (2017b). Türk muhafazakârlı̆̆ı ve inşaat şehveti: Büyük olsun bizim olsun. T. Bora (Der.) içinde, İnşaat Ya Resulullah (s.9-16). İstanbul: İletişim Yayınları.

Calas, M. B. and Smircich, L. (1999). Past postmodernism? Reflections and tentative directions. Academy of Management Review, 24(4), 649-672. 
Callon M. (1997). Society in the making: The study of technology as a tool for sociological analysis. Eds. W. E. Bijker, T. P. Hughes \& T. Pinc, The Social Construction of Technological Systems, 1997, 83-103. Cambridge.

Callon, M. ve Latour, B. (1981) Unscrewing the big leviathan: How actors macrostructure reality and how sociologists help them to do so. (in) K. Knorr Cetina and A. Cicourel (eds), Advances in Social Theory and Methodology: Toward an Integration of Micro and Macro-Sociologies, London, Routledge \& Kegan Paul.

Callon, M. (1986a). The sociology of an actor-network: The case of the electric vehicle. In Mapping the dynamics of science and technology (p.19-34). Palgrave Macmillan, London.

Callon, M. (1986b). Some elements of a sociology of translation: Domestication of the scallops and the fishermen of StBrieuc Bay. J. Law (der) Power, Action and Belief: A New Sociology of Knowledge? in (196-233). London: Routledge and Kegan Paul.

Callon, M. (1999). Actor-network theory-the market test. The Sociological Review, 47(1_suppl), 181-195.

Callon, M., Law, J. ve Rip, A (Hrsg.). (1986): Mapping the dynamics of science and technology. London: Macmillan Press.

Castells, M. (2013). Enformasyon çă̆ı: Ekonomi, toplum ve kültür-ă̆ toplumunun yükselişi Cilt 1 (çev: E. Kılıç). İstanbul: Bilgi Üniversitesi Yayınları.

Chen, Y. S. ve Wu, S. T. (2021). An exploration of actor-network theory and social affordance for the development of a tourist attraction: A case study of a Jimmy-related theme park, Taiwan. Tourism Management, 82, 104206.

Czarniawska, B. (2017). Actor-Network theory. Langley, A. ve Tsoukas, H. (Eds.). The SAGE Handbook of Process Organization Studies. Sage. p.160173.

Çavdar, A. (2020). Kutsal hırsın beton gölgesi: Çamlıca Camii neyin anıtı?, (iç) Otoriter Neoliberalizmin Gölgesinde : Kent, Mekan, İnsan (der. Ş. Geniş). Ankara: Nika Yayınları.

Çelikel, S. B. ve Aydınel, S. (2013). Endüstriyel tasarımda paradigma kaymaları: İşlev/anlam ikiliğinin aşılmasına ilişkin bir teori. Tasarım+Kuram, 15, 720.

Çınar, R. Ü. (2020). Ecdadın icadı AKP iktidarında bellek mücadelesi. İstanbul: İletişim Yayınları. 
Dellaloğlu, B. (2019). Büyük sorular - Türkiye'nin estetik ile imtihanı. Habertürk Tv. Et.25.11.2020.

Diken, B. (1997). Melezlik ve sosyal teori. Toplum ve Bilim, 73, 74-110.

Eryılmaz, M.E. (2019). Suriye mutfağının mülteci girişimciler eliyle Türkiye bağlamına seyahati: Bir çeviri hikayesi. 27. Ulusal Yönetim ve Organizasyon Kongresi. At: Antalya

Farías I.; Blok, A. ve Roberts, C. (2019). Actor-Network theory as a companion: An inquiry into intellectual practices. Blok, A., Farías, I. \& Roberts, C. (Eds.). The Routledge Companion to Actor-Network Theory. Routledge. p.xx- xxxv.

Geertz, C. (2010). Kültürel bir dizge olarak din. (iç) Kültürlerin Yorumlanması (çev:H. Gür). Ankara: Dost Kitabevi.

Gençer, M. (2017). Sosyal ağ analizi yöntemlerine bir bakış. Yıldız Social Science Review, 3(2), 19-34.

Gerekan, B. (2012). Aktör-ağ kuramı kapsaminda stratejï ve muhasebe. World of Accounting Science, 14(2), 49-59.

Giddens, A. (2019). Modernite ve bireysel kimlik (çev: Ü. Tatlican). İstanbul: Say Yayınları.

Gouldner, A. W. (2021). Batı sosyolojisinin yaklaşan krizi (çev: M. Şenol). Sakarya: SAÜ Kültür Yayınları.

Güler, M. (2020). Reklamın ötesine geçmek: Hackvertising. Abant Kültürel Araştormalar Dergisi, 5(10), 50-74.

Gündüz, A. ve Attar, G. E. (2020). Aktör ilişkilerağı, sağlık-hastalık ve suç: Şahsiyet dizisi üzerinden bir tartışma. İnsan ve İnsan, 7(24), 127-153.

Habermas, J. (2018). Sosyal bilimlerin mantığı üzerine (çev: M. Tüzel). İstanbul: Alfa Yayınları.

Hammond, T. (2019). Heritage and the Middle East: Cities, power, and memory. Geography Compass, 14(2), e12477

Justesen, L. (2020). Actor-network theory as analytical approach. Järvinen, M., Mik-Meyer, N. (Edi.) Qualitative Analysis Eight Approaches for the Social Sciences. Sage. p.327-344.

Kasapoğlu, A. ve Odabaşı, Y. (2009). Sosyolojik açıdan teknoloji odağında güncel sorunların yorumlanması. Elektrik Mühendisliği, 436(Haziran), 31-33.

Korkmaz, S. S. (2019). (Re)construction of Turkish National identity in urban space: Transformation of Istanbul's panaroma under JDP rule. In: Nation-Building and Turkish Modernization: Islam, Islamism, and Natio- 
nalism in Turkey / [ed] Rasim Özgür Dönmez, Ali Yaman, Lanham, Maryland: Lexington Books, s.233-254.

Latour, B. ve Woolgar, S. (1979). Laboratory life: The construction of scientific facts. London: Sage Publications.

Latour B. (1991). Technology is society made durable. Ed. J. Law, A Sociology of Monsters: Essays on Power, Technology, \& Domination, 1991, 103-131. London \& New York.

Latour, B., Mauguin, P. ve Teil, G. (1992). A note on socio-technical graphs. Social Studies of Science, 22(1), 33-57.

Latour, B. (1996). On actor-network theory: A few clarifications. Soziale Welt, 47(4), 369-381.

Latour B. (1997). Where are the missing masses? The sociology of a few mundane artefacts. (Eds). W. E. Bijker \& J. Law, Shaping Technology/Building Society: Studies in Sociotechnical Change (1997) 225-258. UK: Cambridge.

Latour, B. (1999a). On recalling ANT. In J. Law \& J. Hassard (Eds.), Actor network theory and after (p.15-25). Oxford: Blackwell.

Latour, B. (1999b). Pandora's hope. London: Harvard University Press.

Latour, B. (2005). Reassembling the social: An introduction to actor-network-theory. Oxford: Oxford University Press.

Latour, B. (2008a). Biz hiç modern olmadık (çev: İ. Uysal). İstanbul: Norgunk Yayınları.

Latour, B. (2008b). Tarde ve toplumsalın sonu. (çev: F. Berksun ve diğerleri). Tesmeralsekdiz, 2(3), 34-49.

Latour, B. (2021). Toplumsal yeniden toplama : Aktör-ă̆ teorisine bir giriş (çev. N. Bingöl). İstanbul: Tellekt.

Law, J. (1992) Notes on the theory of the actor Network: ordering, strategy and heterogeneity. http://www.lancs.ac.uk/ fass/sociology/papers/law-notesonant.pdf ET: 10.01 .2009

Miles, J. A. (2016). Yönetim ve organizasyon kuramları (çev: M. Polat \& K. Arun). Ankara: Nobel Akademik Yayinclik.

Montenegro, L. M. ve Bulgacov, S. (2014). Reflections on actor-network theory, Governance Networks, and Strategic Outcomes. BAR, Rio de Janerio, 11(1), 107-124.

Odabaş, Z. Y. (2010). Sürdürülebilir afet yönetimi ve kadın. Ankara: Ankara Üniversitesi Rektörlüğü Yayınları: 256. 
Odabaş, Z.Y. (2016) Anneliğin siyasal alanda yeniden inşasının ilişkisel sosyolojik eleştirisi, iç. Uygulamalı İlişkisel Sosyoloji (der. A. Kasapoğlu), İstanbul: Yeni İnsan

Oral, B. (2017). 21.yüzyıl Türkiyesi'nde muhafazakar milli mimarlık arayışları ve yansımaları. SDÜ Fen-Edebiyat Fakültesi Sosyal Bilimler Dergisi, 41, 237255.

Oral, B. (2020). Muhafazakâr tutumun estetik sorunsalı bağlamında çağdaş cami mimarisi. Sanat Tarihi Dergisi, 29(2), 489-519.

Özmen, M. (2019). Sosyo-materyal bir yapı olarak pazar: Pazarın bilimteknoloji- toplum incelemeleri bakış açısıyla incelenmesi. Pazarlama Teorisi ve Uygulamaları Dergisi, 5(2), 303-338

Parlak, D. (2020). Laikleşme sürecinde camiler: Geç Osmanli'dan erken Cumhuriyet'e. İstanbul: İletişim Yayınları.

Parlak, İ. ve Aycan, O. (2016). Turkey's memory politics in transformation: Akp's new and old Turkey. (ed) A. Bilgin \& A. Öztürk Political culture of Turkey in the rule of the AKP. Nomos: Almanya.

Pappenheim, F. (2002). Modern insanın yabancılaşması (çev: S. Ak). Ankara: Phoenix Yayınevi.

Sağır, A. (2012). Modernden postmoderne geçişte sosyal bilimlerin felsefi temellerinin sarsılışı. KUTADGUBILIGG, 21, 25-55.

Sarımuratoğlu, D. (2019). Konvansiyonalist cephedeki iç savaş: Aktör-ağ teorisi güçlü programa karşı. Düşünme Dergisi, 15, 26-37.

Seçilmişler, T. ve Yenen, Z. (2011). Koruma sorunsalına ilişkin kuramsal bir değerlendirme: Kurumsalcı (alan yönetimi) ve çoğulcu (aktör ağ teorisi) yaklaşımların karşılaştırılması. Sigma, 3, 375-384.

Sismondo, S. (2016). Bilim ve teknoloji araştırmaları yaklaşımı: Temeller. (çev. Ü. Tatlican). Ankara: Epos.

Terzi, M. (2019). E-government and cyber terrorism: conceptual framework, theoretical discussions and possible solutions. Tesam Akademi Dergisi, 6(1). 213-247. http: //dx.doi.org/10.30626/tesamakademi.528011

Tokdoğan, N. (2018). Yeni Osmanlıcllk: Hinç, nostalji, narsisizm. İstanbul: İletişim Yayınları.

Toki Haber (2020). Çamlıca Camii kentsel dönüşüm alanında inceleme. https://www.tokihaber.com.tr/haberler/camlica-camii-kentsel-donusumalaninda-incelemel, Et.18.11.2020.

Touraine, A. (2018). Modernliğin eleştirisi (çev: H. Tufan). İstanbul: Yapı Kredi Yayınları. 


\section{Kaynakça Bilgisi/Citation Information}

Sağır, A. ve Memiş Sağır, P. (2021). Avangard bir mabed olarak Çamlıca Camisi'nin Aktör-Ağ Teorisi bağlamında çerçevelemesi. OPUSUluslararası Toplum Araştırmaları Dergisi, 18(44), 8333-8361. DOI:10.26466//opus.932364. 